\title{
Pengembangan Media Pembelajaran Berbasis Aplikasi Game dalam Pembelajaran Bahasa Indonesia pada Siswa Kelas XI
}

\section{Development of Game Application-Based Learning Media in Indonesian Learning for Class XI Students}

\author{
Muhammad Aldyka Daniar ${ }^{1, *}$, Rahmat Soe'oed ${ }^{2}$, dan Asnan Hefni ${ }^{3}$ \\ 1,2,3 Magister Pendidikan Bahasa dan Sastra Indonesia, FKIP, Universitas Mulawarman \\ JI. Muara Pahu, Kampus Unmul Gn. Kelua, Samarinda, Kalimantan Timur, Indonesia \\ 1,^ Email: aldyka09@gmail.com; Orcid: https://orcid.org/0000-0003-4166-0163 \\ 2Email: mrsoeoed52@gmail.com; Orcid: https://orcid.org/0000-0002-6913-8185 \\ ${ }^{3}$ EMail: hefni.asnan@gmail.com; Orcid: https://orcid.org/0000-0002-4430-8010
}

\begin{abstract}
ARTICLE HISTORY
Received 27 November 2021 Accepted 30 November 2021 Published 1 February 2022

\section{KEYWORDS}

development, learning media, game applications.

\section{KATA KUNCI}

pengembangan, media pembelajaran, aplikasi game.

ABSTRACT

The aims of this study are to (1) describe the development of game media in Indonesian language learning; (2) reveal the level of interest in using game media in an effective learning process requires media in Indonesian language learning; and (3) knowing the level of effectiveness of using game media in learning Indonesian. This research is development research, with data collection steps according to the development model according to Borg \& Gall. The stages taken in this research are limited to seven stages, namely research and information collecting, planning, developing the preliminary form of product, preliminary field testing, main product revision, main field testing, and operational product revision. The results of the research show that: (1) the development of learning media based on Android games with the support of the Netbeans 12.4 product oracle software; (2) students have a positive attitude towards the product by $81 \%$ in the "very interesting" category; (3) the level of effectiveness of using game media in learning Indonesian is $82 \%$ or very effective. Based on the results of these studies, it can be concluded that web-based games can be used to support learning media for high school students.

\section{ABSTRAK}

Tujuan penelitian ini adalah untuk: (1) mendeskripsi pengembangan media game dalam pembelajaran bahasa Indonesia; (2) mengungkap tingkat kemenarikan penggunaan media game dalam Proses pembelajaran yang efektif memerlukan media dalam pembelajaran bahasa Indonesia; dan (3) mengetahui tingkat keefektifan penggunaan media game dalam pembelajaran bahasa Indonesia. Penelitian ini merupakan penelitian pengembangan. Langkah-langkah pengumpulan data menggunakan model pengembangan menurut Borg \& Gall. Pada penelitian ini hanya diambil tujuh tahap, yaitu studi pendahuluan, perencanaan penelitian, pengembangan desain, uji coba pendahuluan, revisi hasil uji lapangan terbatas, uji coba produk secara lebih luas, dan revisi hasil uji coba lapangan lebih luas. Hasil penelitian menunjukkan bahwa: (1) pengembangan media pembelajaran game berbasis Android dengan dukungan perangkat lunak Netbeans 12.4 product oracle; (2) siswa bersikap positif terhadap produk sebesar $81 \%$ dengan kategori "sangat menarik"; dan (3) tingkat keefektifan penggunaan media game dalam pembelajaran bahasa Indonesia sebesar $82 \%$ atau sangat efektif. Berdasarkan hasil penelitian tersebut dapat disimpulkan bahwa game berbasis web dapat digunakan sebagai penunjang media pembelajaran siswa kelas Sekolah Menengah Atas.
\end{abstract}

\section{To cite this article:}

Daniar, M. A., Soe'oed, R., \& Hefni, A. (2022). Pengembangan Media Pembelajaran Berbasis Aplikasi Game dalam Pembelajaran Bahasa Indonesia pada Siswa Kelas XI. Diglosia: Jurnal Kajian Bahasa, Sastra, dan Pengajarannya, 5(1), 71-82. https://doi.org/10.30872/diglosia.v5i1.332 


\section{A. Pendahuluan}

Era globalisasi masa kini ditandai dengan penggunaan teknologi komputer dan gawai yang semakin meluas di semua bidang kehidupan, terutama bidang pendidikan. Media yang menggunakan teknologi berbasis komputer dan gawai dapat menggabungkan berbagai jenis media yang bertujuan untuk pembelajaran. Media yang beragam meliputi teks, gambar, audio, video, dan animasi. Media yang menggunakan teknologi berbasis komputer dan gawai merupakan kombinasi tiga unsur, yaitu: suara, gambar, dan teks. Kemajuan teknologi informasi dan komunikasi terutama teknologi komputer dan gawai dalam kegiatan pembelajaran bertujuan agar dapat membantu memecahkan masalah belajar yang kerap terjadi (Rahmawati, Leksono, \& Harwanto, 2020).

Hasil survei menunjukkan bahwa salah satu kegiatan yang paling sering dilakukan oleh anak usia 18 tahun ke bawah di gawai adalah bermain game, yaitu sebesar 64\%. Indonesia juga dikatakan sebagai negara dengan jumlah pengunduh terbanyak aplikasi game berbasis Android. Game begitu populer di masyarakat karena membuat pengguna menikmati permainan dan termotivasi untuk terus memainkannya. Media game edukasi di gawai juga memiliki beberapa keuntungan, salah satunya dapat dimainkan kapan pun dan di mana pun. Melalui game edukasi siswa dapat bermain sekaligus belajar dengan cara yang menyenangkan (Salsabila \& Setyaningrum, 2019).

Permainan sebagai media pendidikan mempunyai beberapa kelebihan, yaitu (1) memotivasi minat belajar anak terhadap materi yang dibelajarkan sambil bermain, (2) siswa merasa senang dan nyaman, (3) sebagai sumber belajar mandiri, (4) mengembangkan kemampuan dalam memecahkan permasalahan, (5) meningkatkan rasa percaya diri dalam diri siswa serta harga diri siswa saat mereka mampu menjawab dan menyelesaikan game (Sari, Saputro, \& Hastuti, 2014). Game edukasi telah banyak dikembangkan tetapi game edukasi yang berbasis keterampilan pemecahan masalah sampai saat ini belum maksimal dikembangkan. Oleh karena itu, penting adanya pengembangan permainan sebagai game edukasi yang dapat digunakan sebagai media pembelajaran IPA dalam melatih keterampilan pemecahan masalah yang selanjutnya akan diberi nama science adventure (Winarni, Naimah, \& Widiyawati, 2019). Game ini dikonsep seperti halnya game monopoli yang telah familier bagi anak-anak dan remaja.

Penerapan game edukasi sebenarnya cukup mudah dilakukan dan menyenangkan bagi anak-anak (Winarni et al., 2019). Namun minimnya kajiankajian tentang permainan edukasi menjadi kendala berikutnya sehingga guruguru kesulitan untuk mendapatkan referensi tentang hal ini, apalagi jika permainan edukasi ini harus dispesifikasikan ke dalam mata pelajaran tertentu (mata pelajaran Bahasa Indonesia) (Hidayat, Hidayatullah, \& Agustini, 2019). Padahal menurut teori situated learning, manusia berpikir dan bertindak dengan lebih baik dalam suatu konteks, yaitu dengan memberikan kesempatan bagi pembelajar untuk mengintegrasikan informasi mereka dari berbagai sumber (Alamsyah, Toenlioe, \& Husna, 2018; Prasetiyo, Setyosari, \& Sihkabuden, 2017). Oleh karena itu, kondisi pembelajaran yang tercipta diharapkan bisa diarahkan 
untuk mendorong pembelajar dalam mencari informasi dari berbagai sumber melalui observasi, dan bukan hanya diberi tahu (Maulidina, Susilaningsih, \& Abidin, 2018)

Ada beberapa penelitian relevan terkait penggunaan game dalam pembelajaran. Pertama, penelitian yang dilakukan Nurhabibie (2017) dengan hasil penelitian bahwa pengembangan game edukasi dengan model ADDIE menghasilkan game edukasi yang terdiri atas halaman utama, level game, skor tertinggi, menu materi dan pengaturan. Penilaian oleh ahli materi didapatkan rerata skor 77 dari rerata skor maksimal 104 dengan kategori "layak", sedangkan penilaian oleh ahli media didapatkan rerata skor 93 dari rerata skor maksimal 104 dengan kategori "sangat layak". Penilaian oleh siswa didapatkan rerata skor 63,59 dari rerata skor maksimal 80 dengan kategori "layak". Kedua, penelitian Ramansyah (2016)(2016) menemukan bahwa dengan adanya education game ini maka peserta didik akan lebih mudah dan cepat memahami materi pelajaran, selain itu proses pembelajaran akan lebih menghibur dan menyenangkan. Ketiga, penelitian yang dilakukan oleh Rahmawati, Leksono, \& Harwanto (2020) menemukan bahwa data berupa game petualang untuk pembelajaran berhitung yang dilengkapi buku petunjuk penggunaan bisa diperoleh di Playstore. Validasi ahli isi sebesar $84,76 \%$, validasi ahli media dan desain sebesar 91,82\%, Angket respons siswa terhadap game petualang untuk pembelajaran berhitung mencapai kriteria sangat baik. Keempat, penelitian Salsabila \& Setyaningrum (2019) menemukan bahwa hasil penilaian ahli media menunjukkan skor rata-rata sebesar 152 dengan klasifikasi sangat baik. Dapat disimpulkan bahwa media Game STATIC memenuhi kriteria valid dan layak untuk digunakan dalam pembelajaran matematika. Kelima, penelitian Winarni, Naimah, \& Widiyawati (2019) menemukan bahwa tingkat kelayakan game science adventure yang dikembangkan sebesar 92,5\% untuk materi; dan 95,25\% untuk media. Hasil tes keterampilan memecahkan masalah, mencapai ketuntasan secara klasikal 100\% dengan kriteria sangat baik dengan 82,8 rata-rata nilai siswa. Keenam, penelitian yang dilakukan oleh Nurhidayati (2018) dengan hasil penelitian berupa (1) produk media pembelajaran berbasis Android dalam pembelajaran les articles menggunakan Adobe Flash CS6, (2) penilaian kelayakan yang dilakukan oleh ahli materi memperoleh nilai rata-rata sebesar 2,7 yang termasuk dalam kategori "cukup baik". Sementara penilaian kelayakan yang dilakukan oleh ahli media memperoleh nilai rata-rata 4,0yang termasuk dalam kategori "baik". Uji coba yang dilaksanakan pada kelas XI mendapatkan nilai rata-rata sebesar 4,1 yang termasuk dalam kategori "baik", sedangkan penilaian media oleh guru bahasa Prancis memperoleh nilai rata-rata sebesar 4,6 termasuk dalam kategori "baik".

Berdasarkan uraian di atas, tujuan penelitian ini adalah untuk: (1) mendeskripsi pengembangan media game dalam pembelajaran bahasa Indonesia; (2) mengungkap tingkat kemenarikan penggunaan media game dalam Proses pembelajaran yang efektif memerlukan media dalam pembelajaran bahasa Indonesia; dan (3) mengetahui tingkat keefektifan penggunaan media game dalam pembelajaran bahasa Indonesia. 


\section{B. Metode}

Jenis penelitian yang digunakan adalah jenis penelitian pengembangan (R\&D) yang terdiri atas tahapan penelitian dan pengumpulan data, tahap perencanaan, tahap pengembangan produk, uji coba lapangan (skala kecil), revisi hasil uji coba, uji coba lapangan (skala besar), hasil produk pengembangan dan tahap diseminasi (Apriati, Mulawarman, \& Ilyas, 2021; Sugiyono, 2016). Penelitian ini dilaksanakan pada April 2020 di SMAN 1 Muara Kaman tahun ajaran 2020/2021. Subjek dalam penelitian ini adalah siswa kelas XI IPA SMAN 1 Muara Kaman yang berjumlah 33 siswa. Dengan mengacu pada model pengembangan $R \& D$, peneliti mengambil 7 langkah pengembangan dalam proses ini. Hal ini dilakukan karena penelitian pengembangan dilakukan di sekolah dan menyesuaikan pada karakteristik, keterbatasan waktu, tenaga serta biaya.

Tahap pertama dalam penelitian ini adalah tahap penelitian dan pengumpulan data, tahap ini dilakukan untuk mengkaji situasi dan lingkungan sehingga dapat diketahui produk apa yang perlu dikembangkan, observasi pembelajaran di sekolah. Tahap kedua adalah tahap perencanaan, pada tahap ini dilakukan pembuatan instrumen penilaian dan perancangan (desain) pembuatan produk dari desain materi. Tahap ketiga adalah tahap pengembangan produk, pada tahap ini dilakukan pembuatan dan uji validitas produk (Saputro, Arifin, \& Hefni, 2021). Tahap validitas produk terdiri atas validasi ahli media dan validasi ahli materi serta validasi dari praktisi pembelajaran. Tahap keempat adalah tahap uji coba lapangan. Tahap kelima adalah revisi hasil uji coba, media direvisi sesuai dengan saran perbaikan melalui hasil uji coba kelompok kecil Tahap keenam adalah tahap uji coba kelompok besar, tahap ini dilakukan di SMA Negeri 1 Muara Kaman terdiri atas 33 siswa, jika ada saran atau perbaikan yang perlu diperbaiki selama proses pembelajaran maka media perlu direvisi dan diperbaiki terlebih agar memperoleh media dengan kualitas yang bagus. Tahap ketujuh adalah hasil produk pengembangan, hasil produk pengembangan dalam hal ini adalah produk akhir dari media dalam bentuk jadi yang sudah direvisi dan telah dilakukan uji coba lapangan.

Teknik pengumpulan data pada penelitian ini adalah dengan menggunakan teknik survei, observasi dan tes. Pengumpulan data dengan teknik survei dilakukan dengan memberikan lembar angket validator dan respons siswa, lembar angker validator terdiri atas lembar angker validator ahli media dan ahli materi yang diberikan kepada dosen ahli media, materi dan praktisi pembelajaran., angket validator ini bertujuan untuk mengetahui validitas dari media pembelajaran yang dikembangkan. Lembar angket respons siswa diberikan kepada siswa yang menjadi subjek penelitian, angket respons siswa ini bertujuan untuk mengetahui kepraktisan media pembelajaran yang dikembangkan, melalui angket respons siswa ini juga kita dapat mengetahui tanggapan siswa terhadap media pembelajaran yang telah dibuat, hasil dari respons siswa juga digunakan sebagai bahan pertimbangan untuk merevisi dan penyempurnaan media yang dikembangkan. Selanjutnya teknik observasi. Observasi dilakukan selama penelitian pada saat proses pembelajaran, 
observasi ini dilakukan untuk mengetahui aktivitas guru dan siswa pada proses uji coba dalam pembelajaran. Dalam proses pembelajaran observasi akan dibantu oleh 2 observer yang akan mengamati aktivitas guru dan siswa tersebut terkait pelaksanaan proses pembelajaran yang dilakukan. Selanjutnya teknik analisis data yang digunakan pada penelitian ini adalah sebagai berikut.

\section{Validitas Media Pembelajaran}

Data kualitas media atau data deskriptif kualitatif dalam penelitian ini diperoleh berdasarkan hasil penilaian ahli dan praktisi. Penilaian dilakukan melalui lembar validasi angket media dan materi pembelajaran dengan menggunakan skala Likert dan kolom komentar/saran. Penilaian berdasarkan dua hal yaitu materi dan media pembelajaran kimia yang disajikan dalam bentuk aspek-aspek penilaian. Aspek penilaian media pembelajaran meliputi aspek ukuran, desain kemasan, desain isi dan bahasa dari media pembelajaran, sedangkan aspek penilaian materi meliputi aspek kelayakan isi, aspek kelayakan penyajian dan aspek kelayakan kebahasaan. Data kualitas media pembelajaran dari penilaian dua pakar ahli dan praktisi kemudian dimuat dalam bentuk skala penilaian dan uraian saran. Teknik analisis penilaian validator dihitung dengan menggunakan bobot penilaian angket Sangat Setuju $(S S)=5$, Setuju $(S)=4$, Kurang Setuju (KS) $=3$, Tidak Setuju (TS) $=2$ dan Sangat Tidak Setuju (STS) = 1 (Widyoko, 2012). Data hasil lembar validasi angket yang diperoleh dari validator ahli media, materi dan praktisi pembelajaran kemudian dianalisis dengan menggunakan rumus sebagai berikut:

Berdasarkan persentase yang dihasilkan terhadap validitas media pembelajaran yang dikembangkan menurut rumus: $P=\frac{f}{N} \times 100 \%$, pemberian kriteria validitas mengacu pada Tabel 1.

\section{Kemenarikan Media Pembelajaran}

Teknik analisis data untuk mengetahui kemenarikan media pembelajaran yaitu menggunakan angket respons siswa. Angket respons diberikan kepada siswa yang menjadi subjek penelitian. Angket respons siswa ini bertujuan untuk mengetahui apakah media pembelajaran yang telah digunakan selama proses pembelajaran praktis untuk digunakan. Kepraktisan media dapat dilihat berdasarkan hasil analisis angket respons siswa yang diberikan setelah kegiatan pembelajaran menggunakan media yang dikembangkan. Angket respons yang diberikan kepada siswa menggunakan skala Likert dalam penilaiannya dengan bobot penilaian Sangat Setuju $(S S)=5$, Setuju $(S)=4$, Kurang Setuju $(K S)=3$, Tidak Setuju (TS) $=2$, Sangat Tidak Setuju (STS) $=1$ (Widyoko, 2012). Data hasil angket respons siswa yang diperoleh di hitung dengan menggunakan rumus: $P=$ $\frac{f}{N} \times 100 \%$. Berdasarkan persentase yang dihasilkan dari angket respons siswa yang diperoleh kriteria kepraktisan media pembelajaran ditentukan berdasarkan Tabel 2. 


\section{Efektivitas Media Pembelajaran}

Uji efektivitas dilakukan untuk mengetahui sejauh mana peran pembelajaran dalam membantu siswa untuk memahami materi yang diajarkan. Efektivitas ini dihitung menggunakan rumus: $P=\frac{f}{N} \times 100 \%$. Kriteria keefektivitasan media pembelajaran ditentukan kriteria pada Tabel 3.

\section{Pembahasan}

Penelitian ini merupakan penelitian pengembangan dengan tujuan untuk menghasilkan suatu produk yang dikembangkan, yaitu pengembangan media pembelajaran. Pengembangan yang dilakukan merupakan jenis penelitian dan pengembangan. Model ini terdiri atas beberapa yaitu tahapan penelitian dan pengumpulan data, tahap perencanaan, tahap pengembangan produk, uji coba lapangan (kelompok kecil), revisi hasil uji coba, uji coba lapangan (kelompok besar), hasil produk pengembangan dan tahap diseminasi.

\section{Validitas Media Pembelajaran}

Validitas media pembelajaran dibagi menjadi dua jenis validasi, yaitu validasi ahli media pembelajaran dan validasi ahli materi pembelajaran. Aspek media pembelajaran diukur dari aspek ukuran media, desain kemasan atau tampilan, desain isi dan aspek kebahasaan, sedangkan aspek materi pembelajaran diukur dari aspek isi, aspek kelayakan penyajian dan aspek kelayakan kebahasaan. Berdasarkan hasil validasi oleh validator ahli materi diperoleh hasil sebesar 88 $\%$ dengan kategori sangat baik dan sangat valid. Sedangkan berdasarkan hasil validasi oleh validator ahli media diperoleh sebesar $87 \%$ dengan kategori sangat baik dan sangat valid. Secara keseluruhan, data hasil validasi dari tim ahli dan praktisi pembelajaran telihat pada Tabel 4.

Validasi ahli media melibatkan 1 dosen ahli dari Program Studi Bahasa Inggris Universitas Mulawarman yang ditunjuk sebagai validator. Kedua validator merupakan dosen yang jurusan teknik informasi yang memahami media berbasis teknologi. Adapun tujuan dari validasi media ialah untuk mendapatkan informasi berupa masukan, tanggapan serta saran dari validator terhadap media yang telah dikembangkan. Selain memberikan penilaian berdasarkan pernyataan kuesioner, validator ahli media juga memberikan masukan dan saran lainnya guna tambahan perbaikan terhadap produk yang dikembangkan untuk mendapatkan produk yang lebih baik.

Validasi kedua merupakan validasi dari aspek materi yang terdapat pada media. Validasi materi dilakukan oleh dua dosen yang ahli dibidangnya. Validator diminta untuk menilai isi materi dan kesesuaian materi di dalamnya dengan kurikulum yang ada dengan mengisi lembar angket kuesioner yang telah disediakan. Berdasarkan data hasil validasi media dan materi pembelajaran oleh validator ahli dan praktisi pembelajaran, validitas media pembelajaran yang dilakukan oleh validator ahli media memiliki kategori valid dengan rata-rata 87,5. Sesuai dengan kriteria kevalidan, nilai tersebut berada pada kriteria sangat valid. Berdasarkan hasil validasi tersebut, dapat diambil kesimpulan bahwa kualitas 
media dan materi pada media pembelajaran yang dikembangkan memiliki validitas yang sangat baik (sangat valid) dan layak untuk digunakan dalam proses pembelajaran.

\section{Kemenarikan Media Pembelajaran}

Media pembelajaran adalah alat bantu guru untuk menyampaikan materi agar lebih jelas sehingga siswa lebih memahami materi yang disampaikan oleh guru. Game edukasi merupakan alternatif media pembelajaran sehingga pelajaran lebih menarik dengan siswa dapat berinteraksi secara langsung (Widyastuti \& Puspita, 2020). Kemenarikan diukur melalui hasil angket respons siswa yang diberikan, angket respons siswa ini bertujuan untuk mengetahui kepraktisan media pembelajaran terhadap pembelajaran yang dilakukan.

Berdasarkan hasil respons (Tabel 5) peserta didik terhadap penggunaan media dalam pembelajaran menunjukkan respons sangat baik, baik pada skala kecil dan skala besar yang artinya peserta didik sangat tertarik dengan media yang dikembangkan sehingga membuat aktivitas siswa lebih aktif pada saat proses pembelajaran. Hasil penelitian ini sesuai dengan hasil penelitian Cahyana, Paristiowati, Nurhadi, \& Hasyrin (2017) bahwa penggunaan media mobile game base learning dapat mengembangkan motivasi belajar siswa pada aspek relevansi, perhatian, percaya diri, dan kepuasan. Pada aspek relevansi (relevance) menunjukkan motivasi yang baik dalam hal relevansi ilmu kimia. Pada aspek perhatian (attention), menghasilkan antusias dan perhatian yang baik serta menjadi lebih tertarik terhadap pembelajaran. Untuk Aspek percaya diri (confidence) menghasilkan kepercayaan diri yang baik untuk siswa dalam mempelajari IImu Kimia. Untuk aspek kepuasan (satisfaction) menghasilkan rasa kepuasan yang baik. Siswa juga puas terhadap proses pembelajaran, selain itu siswa juga tidak merasa kecewa dengan proses pembelajaran yang dilaksanakan.

\section{Efektivitas Media Pembelajaran}

Uji keefektifan dilakukan untuk mengetahui sejauh mana peran media pembelajaran dalam membantu siswa memahami materi yang diajarkan. Sebagaimana Tabel 6, hasil penelitian ini menyatakan bahwa penggunaan media game sangat efektif dalam pembelajaran bahasa Indonesia Siswa kelas XI SMA Negeri 1 Muara Kaman. Hasil penelitian ini mendukung penelitian Faqih (2013) yang menyatakan pembelajaran akan lebih menarik, dapat mencari bahan pelajaran dengan mudah, dan pembelajaran tentu akan lebih bervariasi sehingga dapat menimbulkan pembelajaran yang efektif dan terstruktur dengan rapi (Faqih, 2021). Perancangan game edukasi ini dilakukan untuk menunjang media pembelajaran di sekolah dengan cara belajar simulasi melalui game edukasi, dan game edukasi ini merupakan alternatif baru untuk mempermudah proses belajar siswa. Desain media berbasis sains ini telah dievaluasi oleh ahli desain sesuai standar BNSP. Selanjutnya materi yang dipaparkan dalam media sains ini telah 
dievaluasi oleh ahli materi dan telah tervalidasi kesesuaiannya dengan standar kompetensi BSNP (Arifin, U, \& Tomi, 2015).

Pengembangan media pembelajaran dalam bentuk game yang dapat diakses menggunakan gawai Android ini diharapkan mampu memenuhi kebutuhan belajar peserta didik yang dapat diakses di mana pun dan kapan pun. Mengingat bahwa alat komunikasi jenis Andorid banyak digunakan oleh peserta didik selain sebagai alat komunikasi, Android juga digunakan untuk mengakses informasi dari berbagai sumber melalui internet. Selain itu juga aktivitas yang banyak digandrungi di kalangan remaja saat ini ialah bermain game online yang membuat hampir seluruh waktunya dihabiskan untuk mengakses game oleh karena itu pengembangan game edukasi dipilih untuk dapat membantu mengurangi peserta didik mengakses game yang tidak bernilai edukatif. Media pembelajaran berupa aplikasi game edukasi yang dapat dengan mudah diakses dengan menggunakan Android dapat dengan mudah digunakan peserta didik kapan pun dan di mana pun sehingga peserta didik dapat terus belajar tidak hanya dilingkungan sekolah.

Media yang dikembangkan tentunya memiliki kelebihan dan kekurangan. Adapun kelebihan dari media game edukasi yang dikembangkan di antaranya yakni dalam segi materi pembelajaran yang dibuat ringan dan mudah dipahami sebab materi dibuat berdasarkan fakta dan kondisi dalam kehidupan sehari. Selain itu pula penggunaan atau cara bermain yang mudah dan sederhana memudahkan pemain untuk dapat langsung menjalankan game. Media yang dikembangkan mudah diakses bagi pengguna Android sehingga peserta didik dapat terus mengulang kembali pembelajaran kapan pun dan di mana pun. Kelebihan lainnya pada media yang dikembangkan ini adalah media dapat digunakan tanpa koneksi internet atau dapat dijalankan dalam kondisi offline.

Namun berdasarkan penilaian tanggapan dari peserta didik dan guru, diperoleh saran bahwa pada pengembangan aplikasi dapat dikembangkan dalam jangkauan yang sangat luas, artinya aplikasi bisa diakses oleh pengguna Android namun juga bisa diakses bagi pengguna dengan gawai bersistem operasi iOS. Mengingat bahwa aplikasi yang dikembangkan hanya terbatas pada pengembangan hanya untuk pengguna Android dari sistem operasi KitKat hingga terbaru sehingga untuk pengguna iOS tidak memiliki dukungan untuk mengakses game edukasi biologi tersebut. Oleh sebab keterbatasan biaya, maka peneliti memilih untuk mengembangkan aplikasi game berbasis Android, melihat saat hasil pra penelitian pengguna Android lebih banyak dibandingkan pengguna iOS, maka dengan begitu Android dipilih untuk akses penggunaan game yang dikembangkan dan berharap pada penelitian selanjutnya akan meneliti dapat mengembangkan game untuk pengguna gawai jenis Android dan iOS agar dapat digunakan oleh semua kalangan. Kendala lain dalam pengembangan media yang tidak dapat diakses oleh semua pengguna gawai ialah disebabkan karena keterbatasan pengetahuan, waktu dan biaya dalam pengembangan media yang lebih luas.

Berdasarkan penjelasan di atas dapat disimpulkan bahwa aplikasi game pembelajaran bahasa Indonesia pada materi Bahasa Indonesia sangat efektif digunakan sebagai media pembelajaran di kelas XI SMA/ MA. 
Tabel 1. Kriteria Validitas Media Pembelajaran

\begin{tabular}{cc}
\hline Persentase $(\%)$ & Kriteria \\
\hline $81-100$ & Sangat baik \\
$61-80$ & Baik \\
$41-60$ & Cukup \\
$21-40$ & Kurang \\
$0-20$ & Sangat Kurang \\
\hline
\end{tabular}

Tabel 2. Kriteria Kemenarikan Media Pembelajaran

\begin{tabular}{cc}
\hline Persentase $(\%)$ & Kriteria \\
\hline $81-100$ & Sangat Menarik \\
$61-80$ & Menarik \\
$41-60$ & Cukup Menarik \\
$21-40$ & Tidak Menarik \\
$0-20$ & Sangat Tidak Menarik \\
\hline
\end{tabular}

Tabel 3. Kriteria Efektivitas Media Pembelajaran

\begin{tabular}{cc}
\hline Persentase (\%) & Kriteria \\
\hline $81-100$ & Sangat Efektif \\
$61-80$ & Efektif \\
$41-60$ & Cukup Efektif \\
$21-40$ & Kurang Efektif \\
$0-20$ & Sangat Kurang Efektif \\
\hline
\end{tabular}

Tabel 4. Data Hasil Validasi Tim Ahli dan Praktisi Pembelajaran

\begin{tabular}{ccc}
\hline Aspek Penilaian & Skor & Kesimpulan \\
\hline Ahli Media & 87 & Sangat Baik \\
Ahli Materi & 88 & Sangat Baik \\
\hline Rata-Rata & $\mathbf{8 7 , 5}$ & Sangat Baik \\
\hline
\end{tabular}

Tabel 5. Data Hasil Angket Respons

\begin{tabular}{ccc}
\hline Skala Uji & Persentase & Kriteria \\
\hline Skala Kecil & $86,27 \%$ & Sangat Bagus \\
Skala Besar & $81 \%$ & Sangat Bagus \\
\hline Rata-Rata & $\mathbf{8 3 , 6 3 \%}$ & Sangat Bagus \\
\hline
\end{tabular}

Tabel 6. Data Hasil Uji Efektivitas

\begin{tabular}{cccc}
\hline Sekolah & Jumlah Skor & Persentase & Kesimpulan \\
\hline Skala Kecil & 1882 & $85,5 \%$ & Sangat Bagus \\
Skala Besar & 2716 & $82,30 \%$ & Sangat Bagus \\
\hline Rata-Rata & $\mathbf{2 2 9 9}$ & $\mathbf{8 3 , 9 0 \%}$ & Sangat Bagus \\
\hline
\end{tabular}

\section{Penutup}

Berdasarkan hasil penelitian yang telah dilakukan, maka dapat disimpulkan bahwa media pembelajaran yang dikembangkan telah layak digunakan sebagai media pembelajaran bagi siswa dan guru pada mata pelajaran bahasa Indonesia SMA/sederajat karena telah memenuhi kriteria kevalidan, kemenarikan dan keefektivitasan, dengan nilai validitas dari ahli media (87\%), ahli materi (88\%) dengan kriteria keseluruhan sangat valid. Efektivitas media pembelajaran di SMA Negeri 1 Muara Kaman (83\%) dengan kriteria sangat efektif. 


\section{Daftar Pustaka}

Alamsyah, R., Toenlioe, A. J. E., \& Husna, A. (2018). Pengembangan Video Pembelajaran Kepenyiaran Materi Produksi Program Televisi Untuk Mahasiswa Teknologi Pendidikan Universitas Negeri Malang. Jurnal Kajian Teknologi Pendidikan, 1(3), 229-236. Diambil dari http://journal2.um.ac.id/index.php/jktp/article/download/4563/3409

Apriati, L., Mulawarman, W. G., \& Ilyas, M. (2021). Pengembangan Bahan Ajar Menyimak Berbasis Multimedia Interaktif pada Pelajaran Tematik dengan Tema "Indahnya Kebersamaan" untuk Siswa Kelas IV Sekolah Dasar. Diglosia: Jurnal Kajian Bahasa, Sastra, dan Pengajarannya, 4(1), 13-22. https://doi.org/10.30872/diglosia.v4i1.73

Arifin, U, R., \& Tomi, W. I. (2015). Pengembangan media sains berbasis. Jurnal Pembelajaran Fisika, 3(2), 135-146. Diambil dari http://jurnal.fkip.unila.ac.id/index.php/JPF/article/view/8509

Cahyana, U., Paristiowati, M., Nurhadi, M. F., \& Hasyrin, S. N. (2017). Studi Tentang Motivasi Belajar Siswa Pada Penggunaan Media Mobile Game Base Learning Dalam Pembelajaran Laju Reaksi Kimia. JTP-Jurnal Teknologi Pendidikan, 19(2), 143-155.

Faqih, M. (2021). Efektivitas Penggunaan Media Pembelajaran Mobile Learning Berbasis Android Dalam Pembelajaran Puisi. Konfiks: Jurnal Bahasa dan Sastra Indonesia, 7(2), 27-34. https://doi.org/10.26618/konfiks.v7i2.4556

Hidayat, T., Hidayatullah, A., \& Agustini, R. (2019). Kajian Permainan Edukasi dalam Pembelajaran Bahasa Indonesia. Deiksis: Jurnal Pendidikan Bahasa dan Sastra Indonesia, 6(2), 59-68. https://doi.org/10.33603/dj.v6i2.2111

Maulidina, M. A., Susilaningsih, \& Abidin, Z. (2018). Pengembangan Game Based Learning Berbasis Pendekatan Saintifik pada Siswa Kelas IV Sekolah Dasar. JINOTEP: Jurnal Inovasi dan Teknologi Pembelajaran, 4(2), 113-118. https://doi.org/10.17977/um031v4i22018p113

Nurhabibie, F. Y. (2017). Pengembangan Media Pembelajaran Game Edukasi untuk Belajar Mandiri pada Kompetensi Dasar Hidrolik dan Komponen Hidrolik Siswa SMK Negeri 3 Wonosari. Diambil dari https://eprints.uny.ac.id/46611/

Nurhidayati, D. (2018). Pengembangan Media Game Edukatif Berbasis Android dalam Pembelajaran Les Articles Kelas XI SMA. Diambil dari https://eprints.uny.ac.id/61511/

Prasetiyo, T. K., Setyosari, P., \& Sihkabuden. (2017). Pengembangan Media Augmented Reality Untuk Program Keahlian Gambar Bangun di Sekolah Menengah Kejuruan. JINOTEP: Jurnal Inovasi dan Teknologi Pembelajaran, 4(1), 37-46. https://doi.org/10.17977/um031v4i12017p037

Rahmawati, I., Leksono, I., \& Harwanto, H. (2020). Pengembangan Game Petualang untuk Pembelajaran Berhitung. Edcomtech Jurnal Kajian Teknologi Pendidikan, 5(1), 11-23. https://doi.org/10.17977/um039v5i12020p011

Ramansyah, W. (2016). Pengembangan Education Game (Edugame) Berbasis Android Pada Mata Pelajaran Bahasa Inggris Untuk Peserta Didik Sekolah 
Dasar. Edutic - Scientific Journal of Informatics Education, 2(1), 1-9. https://doi.org/10.21107/edutic.v2i1.1560

Salsabila, N. H., \& Setyaningrum, W. (2019). Pengembangan Media Pembelajaran Matematika Berbasis Game: Statistics in Arctic. Mandalika: Mathematics and Educations Journal, 1(1). https://doi.org/10.29303/jm.v1i1.1248

Saputro, A. M., Arifin, M. B., \& Hefni, A. (2021). Pengembangan Bahan Ajar Menulis Cerita Pendek dengan Pendekatan Kontekstual Berbasis Kearifan Lokal pada Siswa Kelas XI SMK. Diglosia: Jurnal Kajian Bahasa, Sastra, dan Pengajarannya, 4(2), 235-246. https://doi.org/10.30872/diglosia.v4i2.98

Sari, K. W., Saputro, S., \& Hastuti, B. (2014). Pengembangan Game Edukasi Kimia Berbasis Role Playing Game (RPG) pada Materi Struktur Atom sebagai Media Pembelajaran Mandiri untuk Siswa Kelas X SMA di Kabupaten Purworejo. Jurnal Pendidikan Kimia, 3(2), 96-104. Diambil dari https://jurnal.fkip.uns.ac.id/index.php/kimia/article/download/3717/2605

Sugiyono. (2016). Metodologi Penelitian Kuantitatif, Kualitatif, dan R\&D. Bandung: Alfabeta.

Widyastuti, R., \& Puspita, L. S. (2020). Pengembangan Media Pembelajaran Berbasis Game Edukasi Pada MatPel IPA Tematik Kebersihan Lingkungan. Paradigma - Jurnal Komputer dan Informatika, 22(1), 95-100. https://doi.org/10.31294/p.v22i1.7084

Widyoko, E. (2012). Teknik Penyusunan Instrumen Penelitian. Yogyakarta: Pustaka Belajar.

Winarni, D. S., Naimah, J., \& Widiyawati, Y. (2019). Pengembangan Game Edukasi Science Adventure untuk Meningkatkan Keterampilan Pemecahan Masalah Siswa. Jurnal Pendidikan Sains Indonesia, 7(2), 91-100. https://doi.org/10.24815/jpsi.v7i2.14462 
M. A. Daniar, R. Soe'oed, \& A. Hefni 